\title{
Studying Ibn Sīnā, Performing Abulafia in a Mid-Sixteenth-Century Prison: Emotional, Medical, and Mystical Bodies between Italy and Silesia
}

\author{
Magdaléna Jánošíková | ORCID: 0000-0002-8695-2453 \\ Department of Jewish History, Ben-Gurion University of the Negev, \\ Beer Sheva, Israel \\ magdalena.janosikova@oxon.org
}

\begin{abstract}
Historians often address knowledge transfer in two ways: as an extension and continuation of an established tradition, or as the tradition's modification in an act of individual reception. This article explores the tension between the two approaches through a case study of Eliezer Eilburg. It traces the footsteps of a sixteenth-century German Jew and his study of the late medieval Hebrew medical and mystical literature composed in the wider Mediterranean. As it uncovers the cultural, political, and social processes shaping knowledge transfer between various Jewish cultures and geographies, the article highlights the receiver's individual agency. Under the thickly described intellectual traditions, it is the receiver's lived experience that allows historians to grasp the impact of knowledge on the lives of premodern people - the impact on their body and its relation to the world and to God. Building this argument, this article problematizes the relationship between theory and practice.
\end{abstract}

\section{Keywords}

transmission of knowledge - body - practice - sixteenth century - Kabbalah medicine - emotions 


\section{Introduction ${ }^{1}$}

Not long after his return from Italy, around the autumn of 1553, Eliezer Eilburg, a Central European Jew born in Lower Saxony, was detained in the Silesian town of Oleśnica (Oels). ${ }^{2}$ During his imprisonment, he immersed himself in activities common among prisoners. ${ }^{3}$ He spent his days with prayer, study, and writing. His copy of Ma'ayan ha-Hokhmah [The Fountain of Wisdom], ${ }^{4}$ included in his kabbalistic miscellany entitled Mahberet ha-Me'assef [The Collector's Notebook], exemplifies this type of writing, addressing the uncanny circumstances of its production in the colophon:

I found this book, [together with] Sefer Raziel in the hands of the "Greek" sages, ${ }^{5}$ the great debaters-i.e., defenders of the rabbinic traditions, experts, the pious kabbalists, and men of [good] deeds. I copied them as I needed them in a hurry in Ancona in Lombardy. ${ }^{6}$ And now in my exile and captivity I have written this book (i.e., Ma'ayan ha-Hokhmah) in the

1 This project has received funding from the European Research Council (ERC) under the European Union's Horizon 2020 research and innovation programme (grant agreement No 801861 ). For their comments and suggestions, I am deeply grateful to the EJJS' guest editors of this issue and the journal's reviewers.

2 On Eliezer Eilburg, see Joseph M. Davis with Magdaléna Jánošíková, Eliezer Eilburg: The Ten Questions and Memoir of a Renaissance Jewish Skeptic (Cincinnati: Hebrew Union College Press, 2020), which contains the translation of Eilburg's first-person account and its Hebrew edition; Joseph M. Davis, "The 'Ten Questions' of Eliezer Eilburg," Hebrew Union College Annual 8o (2009): 173-244; idem, "The 'Ten Questions' of Eliezer Eilburg and the Problem of Jewish Unbelief in the 16th Century," Jewish Quarterly Review 91(3-4) (2001): 293-336; Tamás Visi, "Die Rebellion des Elieser Eilburg gegen die rabbinische Tradition: Eine Episode in der intellektuellen Geschichte des mährischen Judentums," Judaica Bohemiae 46 [Supplement] (2011): 11-32; Magdaléna Jánošíková, Composing Hebrew Medical Literature in the Sixteenth Century: Medicine in the Life and Work of Eliezer Eilburg (PhD diss., Queen Mary University of London, 2020). Note that the scholarship refers to Eilburg also as Eilenburg. Although it is likely that the name refers to the city of Eilenburg in northern Saxony, it is not entirely clear how it was linked to Eilburg's family. I thus follow the spelling that Eilburg himself used (spelling of his name without nun), not to automatically connect it with the city.

3 New York, Jewish Theological Seminary of America (JTSA), Ms 2324, fol. $91 v$.

4 Eilburg refers to the text as Ma'ayan ha-Hokhmot [Fountain of Wisdoms]. On this title, see Oded Porat, "Aimed Inquiry and Positive Theology in 'Sefer Ma'ayan ha-Hokhmah', Journal of Jewish Thought and Philosophy 24 (2016): 224-278.

5 Here, by Greek sages, Eilburg referred to the subjects of the Ottoman Empire, also called the Levantine Jews.

6 Note, Ancona is not located in Lombardy. Eilburg's spelling of Ancona (אנקונייה) is also not standard. 
right order from my [previous] copy without omissions or additions, in accordance to its appropriate [and] complete state. ${ }^{7}$

Prison gave Eilburg the convenience of time to review his manuscripts, re-order them, and reflect on them. But as Ruth Ahnert has pointed out, filling prisoners' "spare" time was only one of the functions which writing facilitated. Studying, commenting, and copying, along with prayer and meditation, belonged to the few activities that compensated for their loss of agency and gave them a voice by which to at least symbolically resist its institutional silencing. ${ }^{8}$ For Eilburg, prison was not a passive background; its significance went beyond a biographical curiosity mentioned in prologues and colophons as Ma'ayan ha-Hokhmah may suggest. ${ }^{9}$ But neither was imprisonment at the core of his writing. It did not drive the narration, the spiritual purgation, and the self-realization as it did in the case of Abraham Yagel's (d. 1623) Ge Hizayon [The Valley of Vision]..$^{10}$ Eilburg's references to prison were far less systematic. Yet his comments reveal that he grappled with his new environment. His emotional state was inscribed into his studies, bestowing on the process the framework of a lived experience.

This experience, while individual in Eilburg's case, is also indicative of a larger process. The late sixteenth century is often portrayed as the time of an Ashkenazic intellectual revival. According to Majer Bałaban, Jacob Elbaum, and Elchanan Reiner, the "discovery" of late medieval Sephardic and Italian intellectual heritage and the import of printed books primarily designed for the

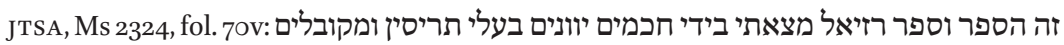

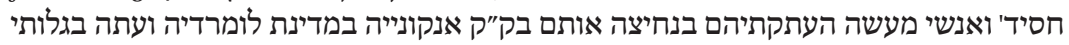
ובשביותי כתבתי זה הספר כסדר בחק הישר מהעתקת בתי בלי חסרון אוניה במדי יותר לפי שלימותו.

8 Ruth Ahnert, The Rise of Prison Writing in the Sixteenth Century (Cambridge: Cambridge University Press, 2013), 31-32. On prison writing, see also Thomas S. Freeman, "The Rise of Prison Literature," Huntington Library Quarterly 72 (2009): 137-146; on prison writing in Central Europe, see Martin Scheutz, "Ist mein schwalben wieder ausbliben.' Selbstzeugnisse von Gefangenen in der Frühen Neuzeit," Comparativ $5^{-6}$ (2003): 189-210; Gerold Hayer and Ulrich Müllwe, "Flebilis heu maestos cogor inire modos': 'Gefängnis-Literatur' des Mittelalters und der Fall des württembergischen Grafen Heinrich (1448-1519)," in Licht der Natur: Medizin in Fachliteratur und Dichtung, Festschrift für Gundolf Keil zum 6o. Geburtstag, eds. Josef Domes et al. (Göppingen: Kümmerle, 1994), 171-193 (179-182).

9 In these terms, Susan Einbinder described a collection of medieval Jewish prison writings. Cf. Susan Einbinder, "Prison Prologues: Jewish Prison Writing from Late Medieval Aragon and Provence," Journal of Medieval Religious Cultures 38 (2012): 137-158 (152).

10 Cf. David B. Ruderman (ed. et tr.), A Valley of Vision. The Heavenly Journey of Abraham ben Hananiah Yagel (Philadelphia: University of Pennsylvania Press, 1990), 23-50; Marcus Moseley, Being for Myself Alone: Origins of Jewish Autobiography (Stanford: Stanford University Press, 2006), 84-94. 
Italian Jewish market played a major role in this development. ${ }^{11}$ Eilburg — born in Braunschweig in Lower Saxony, and active in Poland, Silesia, and Italy—was one of many Jews who actively participated in the expansion of Ashkenazic geographical, intellectual, and cultural horizons associated with the sixteenthcentury Ashkenaz. In Italy, he recognized the cultural capital of the late medieval Sephardic and Italian scholarship and brought it back with him to (East-) Central Europe. Eilburg not only moved the texts; he also reworked them in a manner that presupposed an additional audience. The autograph manuscripts entitled Mahberet ha-Me'assef ${ }^{2}$ and Ma'arekhet Refu'ot ha-Shamayim [Medical Hierarchies of the Heavens] ${ }^{13}$ thus form a suitable foundation to investigate the particularities of this transmission and reception of-from Eilburg's perspective - novel and attractive knowledge.

Eilburg's suffering inscribed into his texts, moreover, reminds us that such knowledge transmissions were never disembodied. Historians such as Lyndal Roper have emphasized that "[b]odies are not merely the creations of discourse."14 In his call for the return of "flesh and blood" to the sociology of knowledge, Loïc Wacquant theorized that men and women are thoroughly situated, sentient, suffering, skilled, sedimented as they learn, study, and practice

11 Majer Bałaban, "Umysłowość i Moralność Żydostwa Polskiego XVI Wieku” [Mentality and Morality of Polish Jews in the Sixteenth Century], in Kultura Staropolska (Kraków: Polska Akademja Umiejętności, 1932), 6o6-639; Jacob Elbaum, Openness and Insularity: Late Sixteenth Century Jewish Literature in Poland and Ashkenaz (Jerusalem: Magnes, 1990), 17 [Hebrew]; idem, "Cultural Connections between Polish and Askenazic Jews and Italian Jewry in the Sixteenth Century," Gal-Ed 7-8 (1985): 11-40 [Hebrew]; idem, "The Influence of Spanish-Jewish Culture on the Jews of Ashkenaz and Poland in the Fifteenth-Seventeenth Centuries," Binah 3 (1994): 179-197 [Hebrew]; Elchanan Reiner, "No Jew Should Learn Anything but the Talmud Alone': A Dispute over Books and Forbidden Books in 16th Century Ashkenaz," Ta-Shma: Studies in Judaica in Memory of Israel M. Ta-Shma, vol. 2, eds. Abraham Reiner et al. (Allon Shvut: Tevunot, Herzog College, 2011), 705-746 [Hebrew]; idem, "The Old for the New: On Changes in Curricula of Polish Jewish Academies in the Sixteenth Century and the Cracow Academy of Rema," in Zekhor Davar le-'Avdekha: Essays and Studies in Memory of Dov Rappel, ed. Shmuel Glick (Jerusalem: Lifshitz College, 2006), 183-206 [Hebrew].

12 JTSA, Ms 2324.

13 JTSA, Ms 2692. Note on the title's translation: the title translates into modern Hebrew as Medical Systems of the Heavens. In medieval technical Hebrew, it more accurately refers to Medical Constellations of the Heavens. Although the manuscript contains some medical astrology, by "constellation" instead Eilburg implies the organization, the inner order of all elements of practical medicine, which Eilburg introduces step-by-step. Thus, the term "hierarchies," or perhaps "harmonies" (similarly as in some of the English translations of Ma'arekhet ha-Elohut) is far more suitable.

14 Lyndal Roper, Oedipus and the Devil: Witchcraft, Sexuality and Religion in Early Modern Europe (London: Routledge, 1994), 21. 
their crafts. ${ }^{15}$ In their footsteps, this article aims to show that Eilburg's reception of kabbalistic and medical knowledge was not only a theoretical placement of self on the disembodied mystical and medical system of knowledge. The transfer and reception were driven by his biographical and physical circumstances. They answered his practical needs. More specifically, the studied materials enabled him to make sense of his dire condition during the imprisonment and even gave him practical solutions to aid his situation, giving him tools to mold his emotional life. This article thus aims to redirect our attention from the theory and the myth as an organizing principle of practice to highlight the active role of practice in the theory's validation, refutations, and adjustments. ${ }^{16}$

To reach such a conclusion, this case study explores the transmission of medical and kabbalistic knowledge in three parts, exploring the full scope of social, cultural, intellectual, and personal motivations and events that drove the transmission - the subject of this special volume. In the first part, I situate Eilburg's biography into the bigger picture of the social, economic, cultural, and even political transformation of Central and Eastern European Jewry. In the second part, I establish Eilburg's two autograph manuscripts, Maḥberet haMe'assef and Ma'arekhet Refu'ot ha-Shamayim, as materials - texts as well as things - that reflect on Eilburg's first experience with Italy and its later reworking in East-Central Europe. In the third part, I examine whether the scholarly traditions that Eilburg obtained in Italy and promoted in Central Europe were only ideas transported or rather ideas studied, practiced, and experienced. I use Eilburg's remarks about his time in prison to demonstrate how he applied the scholarly traditions associated with the medieval and Renaissance Jews of the Mediterranean (in particular, the epistemological concepts which addressed knowing and emotions as bodily and naturalized processes) to frame his recollections and actions.

\footnotetext{
15 Loïc Wacquant, "For a Sociology of Flesh and Blood," Qualitative Sociology 38 (2015): 1-11 (3-4). Note, that I do not borrow the whole sociological model of carnal sociology, but reflect on the critique of network-driven portrayal of agents as active minds mounted on absent bodies.

16 For similar emphasis, see Agata Paluch's work, where she shows that practices formerly studied as part of elite kabbalistic teachings were performed by "people of all walks of life," thus problematizing the relationship between theory and practice. See Agata Paluch, "Intentionality and Kabbalistic Practices in Early Modern East-Central Europe," Aries: Journal for the Study of Western Esotericism 19 (2019): 102.
} 
Eilburg's life is a telling example of how the Jews of Central Europe adapted to the changing political, economic, and social developments of the sixteenth century. Over the course of twenty years, he underwent a complete occupational makeover. A well-established merchant from Lower Saxony turned into a Jewish tutor and a physician active in East-Central Europe and in Northern Italy. This transformation took place against the backdrop of rising geographical mobility, exchange of expertise and goods, and remodeled local concepts of Jewish culture and scholarship. ${ }^{17}$

Eilburg was born as the third generation of merchants in Braunschweig. This city housed his extended family until the end of 1546 , when the expulsion of local Jews, as Rotraud Ries has observed, transformed the pattern of the Jewish settlement in this region entirely. ${ }^{18}$ His family played a crucial role in the town; Eilburg's grandfather Akiva and later his uncle Jorden were the leading members of the local Jewish community, which just before its dispersal numbered almost one hundred. ${ }^{19}$ They raised their objection, as they had done on other occasions, and attempted to have the expulsion decree overturned. ${ }^{20}$ Unsuccessful, the Jews left this then-Lutheran town at the time of war with the Imperial defender of Catholicism, Charles v (d. 1558). ${ }^{21}$

Eilburg's extensive family dispersed completely. Although the expulsion in 1546 was not the first revocation of their residential rights in Braunschweig,

17 David B. Ruderman, Early Modern Jewry: A New Cultural History (Princeton: Princeton University Press, 2010), 23-57.

18 On the expulsion, see Rotraud Ries, 'Der joden to verwisen'-Judenvertreibungen in Nordwestdeutschland im 15. und 16. Jahrhundert," in Judenvertreibungen in Mittelalter und früher Neuzeit, eds. Friedhelm Burgard et al. (Hannover: Verl. Hagnsche Buchhandlung, 1999), 189-224; Dean Phillip Bell, "Jewish Settlement, Politics, and the Reformation," in Jews, Judaism, and the Reformation in Sixteenth-Century Germany, eds. Dean Philip Bell and Stephen G. Burnett (Leiden: Brill, 2006), 421-45o (431-432); idem, Jewish Identity in Early Modern Germany: Memory, Power and Community (Aldershot: Ashgate, 2007), 77-80; Roni Weinstein, "Jews and Lutheranism: An Ambiguous Silence," in Martin Luther. A Christian between Reforms and Modernity (1517-2017), ed. Alberto Melloni (Berlin: de Gruyter, 2018), 635-648 (636-638).

19 Rotraud Ries, "Zum Zusammenhang von Reformation und Judenvertreibung: Das Beispiel Braunschweig," in Civitatum Communitas: Studien zum europäischen Städtewesen: Festschrift Heinz Stoob zum 65. Geburtstag, eds. Heinz Stoob and Helmut Häger, vol. 2 (Cologne: Böhlau, 1984), 630-654 (637).

20 Braunschweig, The City Archive in Braunschweig, B IV 100 Nr. 2.

21 On the Schmalkaldic War (1546-1547), see Thomas Kaufmann, Konfession und Kultur: Lutherischer Protestantismus in der zweiten Hälfte des Reformationsjahrhunderts (Tübingen: Mohr Siebeck, 2006), 43-45. 
its outcome altered their strategy of resettlement. ${ }^{22}$ Instead of returning to Braunschweig, they sought new residencies in neighboring towns, as well as in distant locations. His uncle Jorden and his sons-in-law settled in Münden, where they found protection under Duchess Elisabeth of Calenberg. ${ }^{23}$ Eilburg's widowed mother and his brother moved to Safed. ${ }^{24}$ Eilburg, his wife, and children settled in the Crown of Poland. ${ }^{25}$ According to the document penned by the Polish royal chancery, the Jews of Poznań supported his plea for protection. ${ }^{26}$ Thus, Eilburg likely followed his more distant business partners to a new town, in a new jurisdiction, hoping to continue his former mercantile activities. However, he only recounted failed business partnerships in Poland, and eventually, he fled the country. ${ }^{27}$

Eilburg's financial instability was not a recent development. It followed him from Lower Saxony to Poland. The protracted trial between Eilburg and Johann zum Hoffe, a former resident of Braunschweig who had earned the protection of Brandenburg's prince elector Joachim II (d. 1571), disclosed that Eilburg's financial situation was already dire in the 1540 s. $^{28}$ After losing residency in Braunschweig, he also lost the town's protection. He faced the danger of continuing the trial in Brandenburg and was therefore doomed to lose his property and freedom. In Mahberet ha-Me'assef, this conflict is personalized in the figure of Michel von Derenburg (d. 1549), the court Jew in the services of Joachim II. ${ }^{29}$ According to his own account, Eilburg "refuted him [Derenburg]

22 On the Knoblauch host desecration affair (1510), which affected Eilburg's grandfather, his father, and uncles, see Adolph Friedrich Riedel (ed.), Codex diplomaticus Brandenburgensis. Sammlung der Urkunden, Chroniken und sonstigen Quellenschriften für die Geschichte der Mark Brandenburg und ihrer Regenten, vol. 3 (Berlin: F. H. Morin, 1861), 176-177; David Kaufmann, "Die Märtyrer des Berliner Autodafé," Magazin für die Wissenschaft des Judentums 18 (1891): 49-52 (51); Davis, Eliezer Eilburg, 36; JTSA, Ms 2324, fol. 89r; on Eilburg's own loss of residential rights due to malpractice and libel, see Braunschweig, The City Archive in Braunschweig, B II 2:4 (29 August 1536).

23 Rotraud Ries, Jüdisches Leben in Niedersachsen im 15. und 16. Jahrhundert (Hannover: Hahn, 1994), 81.

24 JTSA, Ms 2324, fol. 89r; on the phenomenon of Jewish widows moving to Palestine, see Ada Rapoport-Albert, "Glikl Hameln as a Widow," in Hut shel Hen. Studies in the Honour of Chava Turnianski, eds. I. Bartal et al. (Jerusalem: The Zalman Shazar Center for Jewish History, 2013), 379-392 (389-391) [Hebrew].

25 JTSA, Ms 2324, fol. 89r; Davis, Eliezer Eilburg, 188-189.

26 Warsaw, Archiwum Główne Akt Dawnych w Warszawie, Metryka Koronna 4-1, sign. 73, fol. $344 \mathrm{v}-346 \mathrm{v}$.

27 JTSA, Ms 2324, fol. 89r-89v; Davis, Eliezer Eilburg, 194-198.

28 Braunschweig, The City Archive in Braunschweig, B IV 10a, Nr. 6; Braunschweig, The City Archive in Braunschweig, B IV 15a, Nr. 157.

29 JTSA, Ms 2324, fol. 89r; Davis, Eliezer Eilburg, 194. 
in front of all the governors of the kingdom, and he was shamed and disgraced and did not know how to answer in front of the governors and noblemen."30 The situation described here likely depicts Eilburg's negotiations for residential rights in the Crown of Poland, which took place in Piotrków Trybunalski. Eilburg received his safe conduct in November $1547 .^{31}$ The royal chancery also recorded his financial ill-health, and the safe conduct stipulated conditions for its renewal—namely, settling his debts within a year. ${ }^{32}$ The flight from Poland over a year later reveals that turning this momentum into successful resettlement was beyond his options.

Eilburg returned to East-Central Europe in Av 5113 (ca. July 1553). He arrived at Oleśnica in Silesia, the region under the jurisdiction of the Bohemian Crown administered by the Podiebrads. ${ }^{33}$ By this time, he no longer presented himself only as a merchant. He also considered himself a tutor-a man well-read in the Bible and its exegesis, including its mystical interpretation-and a physician. He stated to have explored these two occupational avenues in Italy. $\mathrm{He}$ found there his "reawakening" 34 along "the experts and savants in medicine [as they study] from [the works of] Aristotle, Ibn Sīnā, and the other princes," whom he followed "to their palaces openly and secretly" (i.e., he studied exoteric as well as esoteric teachings), "exploring and investigating all essential matters until I understood them correctly." 35

Such an occupational combination was common in fifteenth- and sixteenthcentury Italy ${ }^{36}$ That Eilburg adopted it, together with the knowledge and scholarship that framed it, is later corroborated by documents of Italian provenance. The notarial record from 1564, written in Monza near Milan, addresses Eilburg as a physician. ${ }^{37}$ It mentions his former employers, Venetian silk traders

\footnotetext{
30 Cf. m Avot 5:7; Translation taken from Davis, Eliezer Eilburg, 194-195. Cf. JTSA, Ms 2324, fol. $89 v$.

31 Warsaw, Archiwum Główne Akt Dawnych w Warszawie, Metryka Koronna 4-1, sign. 73, fol. $344 \mathrm{v}-346 \mathrm{v}$.

32 Ibid., fol. $346 \mathrm{r}$.

33 JTSA, Ms 2324, fol. 89v; Davis, Eliezer Eilburg, 215.

34 Ibid., fol. 94r.

35 Translation my own; see also Davis, Eliezer Eilburg, 223; JTSA, Ms 2324, fol. 94r. On his stay in Italy in the early 1550s, see also JTSA, Ms 2324, fol. 70v; JTSA, Ms 2692, fol. 24 r.

36 Cf. Robert Bonfil, Rabbi and Jewish Communities in Renaissance Italy (Oxford: Oxford University Press, 1990), 16o-162.

37 Milan, The City Archive of Milan, Notarile di Milano, Abbiati Agostino (1540-1583), f. 11422 (10 January 1564).
} 
Anzolo and Mandolin, who likely hired Eilburg as a tutor. In 1568 and 1569, he taught the sons of two merchants in San Salvatore Monferrato. ${ }^{38}$

The immediate occupational makeover was, however, initially halted by the imprisonment. There is no archival document that would shed light on this incident. Eilburg, the only source, skillfully hid any hints that would disclose what exactly brought him to ill-repute. According to his first-person account, he arrived to Oleśnica in late summer and was detained there in early autumn after falling ill and being informed on by a certain Abraham Glatzer (likely Abraham Syller, a medical doctor who was in service of the Podiebrads at the time). ${ }^{39}$

In a note of Italian provenience written a decade later, Eilburg remembered the place of his imprisonment differently. He identified it not with Oleśnica but Nysa. ${ }^{40}$ It is, therefore, sound to question the nature of Eilburg's imprisonment. As Susan Einbinder has asked of other Jewish prison-writers: was their imprisonment real or a literary fiction? The sheer volume of Eilburg's references to his imprisonment in Mahberet ha-Me'assef and Ma'arekhet Refu'ot ha-Shamayim suggest that its impact was very real. Eilburg composed a dirge calling for the deliverance of the imprisoned dating to $1554 \cdot{ }^{41}$ Another poem, written down in December 1555, celebrated Eilburg's release. ${ }^{42}$ In a copy of a letter to his cousin Mordecai, Eilburg described his captivity, ${ }^{43}$ and in his biographical account referred to Mordecai as a man who "brought light to his eyes by observing the mișwah of the redemption of captives [pidyon shevuyim]" and "raised his voice on my behalf like an advocate."44

38 JTSA, Ms 2323, fol. 149v; translation in David, Eliezer Eilburg, 255-256.

39 See Antonio Favaro (ed.), Atti della nazione germanica artista nello studio di Padova (Venice: a spese della società, 1911), 6-7; Wrocław, Archiwum Państwowe, Księstwo Oleśnickie, I. 7.g (1551). Note that Eilburg referred to Syller as Abraham Glatzer (Abraham from Kłodzko in Lower Silesia, neighboring Oleśnica). The documents from Padua address him as originating from Nysa in Silesia. Syller was also active in Wrocław and served the nobility in Legnica and Brzeg. Several of his consilia are preserved in the printed books of other Central European physicians. Cf. Johann Heinrich Cunradi, Silesia togata (Liegnitz: Rorlach, 1706), 286; Raphael Finckenstein, "D. Sennert und die schlesischen Ärzte des 16. und 17. Jhs. (II)," Deutsche Klinik 14 (1868): 125-128.

40 JTSA, Ms 2323, fol. 83r.

41 Ibid., fol. 191v. The chronograph refers to "the Almighty" [shaddai] [=(5)314].

42 JTSA, Ms 2324, fol. 61r-62r. The chronograph is derived from Est 8:16 referring to $27 \mathrm{Kislev}$ 5316 (11 December 1555 in the Julian calendar).

43 JTSA, Ms 2324, fol. 2r-3r.

44 Ibid., fol. 89r; translation my own; phrasing references b. Bava Meși'ah 85a. Cf. Davis, Eliezer Eilburg, 19o. 


\section{Writing and Studying between Italy and Central Europe}

Mahberet ha-Me'assef and Ma'arekhet Refu'ot ha-Shamayim closely reflect on the developments in East-Central Europe in the mid-1550s. The two manuscripts were written on paper produced in Silesian paper mills in the 155 os. $^{45}$ They are further tied together by paleographical, codicological, and other paratextual features, which also reveal that their stages of production were intertwined. ${ }^{46}$ In Maḩberet ha-Me'assef, Eilburg identified Oleśnica as the place where he had begun compiling his manuscript. ${ }^{47}$ In the same town, he was also apprehended and imprisoned. ${ }^{48}$ Eilburg thus produced these two manuscripts mostly around late 1554 and 1555 , and possibly later. They thus reflect his recent return from Italy, an aspiration to resettle in Central Europe, and an ambition to reframe his own occupational profile, then interrupted by the incarceration. ${ }^{49}$

Furthermore, Mahberet ha-Me'assef reveals that Eilburg was one of the facilitators of what Elchanan Reiner termed a new Ashkenazic library. ${ }^{50}$ It was an emerging rabbinic curriculum that resulted from the systematic study of the late medieval non-Ashkenazic exegetes and philosophers by Central and Eastern European Ashkenazic Jews. It led to polemical exchanges that targeted the content of the Ashkenazic rabbinic curriculum, culminating in the so-called Poznań debate dating around $1559 .{ }^{51}$ Eilburg's list of books that he

45 Mahberet ha-Me'assef (JTSA, Ms 2324) contains two types of papers: one produced in Nysa and one in Świdnica. The Nysa-produced paper contains a watermark with a motif of fleur-de-lis, similar to Briquet no. 6944 dated to $155^{2}$ (vol. 2, 387). On the paper mill in Nysa, see Joanna Ważyńska and Józef Dąbrowski, “Średniowieczny śląski rękopis kościelny cennym źrodłem filigranów," Przegląd papierniczy 54 (1998): 403-406, 423-424; Józef Dąbrowski, "Paper Manufacture in Central and Eastern Europe Before the Introduction of Paper-making Machines," http://www.paperhistory.org/dabro.pdf, accessed 10 June 2020. For the paper produced in Świdnica, cf. Briquet nos. 6943-6945, 7070 (vol. 2, 387, 391). On the paper mill in Świdnica, see Dąbrowski, "Paper Manufacture," 23; Ważyńska and Dąbrowski, "Średniowieczny śląski rękopis," 403-406.

46 Jánošíková, Composing Hebrew Medical Literature, 47-57.

47 JTSA, Ms 2324, fol. 9ov; Davis, Eliezer Eilburg, 203.

48 The incident is discussed later in the text.

49 JTSA, Ms 2324 was possibly edited also later. The subject requires further assessment. JTSA, Ms 2692 was wholly produced in Silesia in the mid-155os.

50 Reiner, "No Jew," 730-734.

51 On the Poznań debate, see ibid.; Philip Bloch, "Der Streit um den Moreh des Maimonides in der Gemeinde Posen um die Mitte des 16. Jahrhundert," Monatsschrift für die Geschichte und Wissenschaft des Judentums 47 (1903): 153-169, 263-279, 346-356; B. Suler, "Ein Maimonides-Streit in Prag," Jahrbuch für die Geschichte der Juden in der Czechoslovakischen Republik 7 (1935): 411-420. 
mastered - an eloquent piece of his scholarly self-promotion written just a few years prior to the debate-mentions many authorities that became contested by one camp and endorsed by another. Eilburg extolled Maimonides (d. 1204), Abraham ibn Ezra (d. 1167), Bahya ibn Paquda (d. 1120), David Qimhị (d. 1235), Nahmanides (d. 1270), Gersonides (d. 1344), Joseph Albo (d. 1444), Isaac Arama (d. 1494), and the Bible commentary of Bahya ben Asher (d. 1340), which Eilburg requested while lying sick in his bed. ${ }^{52}$

Eilburg not only transported these mystical and medical teachings from one location to another. He also reworked them in a manner that displays his thorough involvement with their study. His list of kabbalistic literature-a piece of self-promotion revealing his ambition to be a tutor-includes commonly studied titles such as Sha'arei Orah, Ma'arekhet ha-Elohut, along with Sefer Yeșirah and commentaries and works associated with its study. ${ }^{53}$ Yet Eilburg dedicated the greatest effort to the works of Abraham Abulafia (d. 1291), whose legacy played an intrinsic role in establishing the Italian model of a late medieval and Renaissance Jewish scholar. ${ }^{54}$ Eilburg's manuscript contains Abulafia's Hayyei ha-'Olam ha-Ba [The Afterlife], and refers to Get ha-Shemot [Divorce of the Names] and Eș ha-Hayyim [Tree of Life].$^{55}$ But none of Abulafia's works was celebrated more than Imrei Shefer [also as Imrei Shafer; Words of Splendor]. The title seals Eilburg's booklist with the exhortation that "no man will become a wise man or a scribe until he learns" it. ${ }^{56} \mathrm{He}$ even recounted a story of the book's "liberation" from the hands of Christian monks who had kept it in the abbey in Seitenstetten. ${ }^{57}$ Visiting the abbey, Eilburg was shown Hebrew books and

52 JTSA, Ms 2324, fol. 94r (on the comment concerned with Bahya ben Asher), fols. 10ov-101r.

53 Ibid.; Davis, Eliezer Eilburg, 249-25o. For study materials in the sixteenth-century Ashkenaz, see Uri Safrai, “'What the One Omits, the Other Reveals': The Perception of Perfection in the Writings of Rabbi Naphtali Hirsch Treves," Kabbalah 35 (2016): 183-204 (190-191) [Hebrew].

54 Moshe Idel, The Mystical Experience in Abraham Abulafia (Albany: State University of New York, 1988); idem, Language, Torah, and Hermeneutics in Abraham Abulafia (Albany: State University of New York, 1989); idem, Abraham Abulafia's Esotericism (Berlin: De Gruyter, 2020); and especially idem, "The Study Program of Yohanan Alemano," Tarbiz 48 (1979): 331 [Hebrew]; see also Elliot R. Wolfson, Abraham Abulafia: Kabbalist and Prophet-Hermeneutics, Theosophy, Theurgy (Los Angeles: Cherub Press, 200o). JTSA, Ms 2324, fol. 94r.

56 Ibid.

57 This is mentioned in JTSA, Ms 2692, fol. 27r, where he seems to be reproducing the same story from another angle. He also mentioned that he arrived there from Styria. 
ripped my clothes [in mourning.] For I have never seen books such as these, never before that time and not since. Some of them were written on giant parchments, and had gilded letters. They had designs of circles drawn on them, and Holy Names, and șerufim of the Ineffable Name, and its mysteries. But I wisely succeeded in acquiring Eș ha-Hayyim and Imrei Shefer, the root of the teaching and their summit, ${ }^{58}$

deeming Abulafia's works worth saving with his limited means. Eventually, Imrei Shefer gave Eilburg a textual framework to convey his personal experience, interweaving the book's excerpt into his first-person account. ${ }^{59}$

The materials present or mentioned in Mahberet ha-Me'assef thus represent texts closely associated with the influence of other non-Ashkenazic Jewries. These are emphasized in the otherwise limited reception of Abulafia in Central Europe, in contrast to his prominence in Italy. And yet Eilburg's predilection for mystical practices related to the Holy Names and his deep interest in Sefer Yeșirah and other practices also reveal Eilburg's unmistakably Ashkenazic filter, through which he related to these works. ${ }^{60}$

The attempt to reach beyond the Ashkenazic library is far more visible in Ma'arekhet Refu'ot ha-Shamayim. This medical manuscript is filled with Latin-to-Hebrew translations of fourteenth-century treatises, mostly of Provençal origins. It contains the Hebrew translations of Gerard de Solo's (fl. 1335-1344) On Fevers; ${ }^{61}$ Hippocrates' (d. ca. 370 BCE) Prognostics; ${ }^{62}$ Ibn Sīnā’s On Cardiac Drugs; ${ }^{63}$ translated from Latin; and pseudo-Villanova's On Judgements of Astronomy; ${ }^{64}$ in addition to Klal Qațan [Concise Summary], composed by Catalan astronomer David ben Yom Ṭov (d. before 1361). ${ }^{65}$ These

$5^{8}$ Translation taken from Davis, Eliezer Eilburg, 220. Cf. JTSA, Ms 2324, fol. 92r.

59 Davis, ibid., 42; JTSA, Ms 2324, fol. 92v-93r.

6o On the Kabbalah in Ashkenaz (and their focus on practices), see Paluch, "Intentionality and Kabbalistic Practices"; idem, "Copying, Compiling, Commonplacing in Kabbalistic Manuscript Collectanea: 'Sefer Heshek and the Kabbalah of Divine Names in Early Modern Ashkenaz," in Representing Jewish Thought, ed. Agata Paluch (Leiden: Brill, 2021), 100-125. See also Moshe Idel, "One from a Town, Two from a Clan: The Diffusion of Lurianic Kabbala and Sabbateanism. A Re-Examination," Jewish History 7 (1993): 79-104; idem, "Between Ashkenaz and Castile in the Thirteenth Century: Incantations, Lists, and 'Gates of Sermons' in the Circle of Rabbi Nehemiah ben Shlomo the Prophet, and their Influences," Tarbiz 77 (2008): 475-554 [Hebrew]; Safrai, "What One Omits."

61 JTSA, Ms 2692 , fol. 1r-6v.

62 Ibid., fol. 1or-13r.

63 Ibid., fol. 13v-17v.

64 Ibid., fol. $23^{r-31 v}$.

65 Ibid., fol. $23 \mathrm{v}-3$ or. 
sources circulated south of the Alps for almost two centuries, but had only begun to emerge in Central Europe as well-received media communicating scientific knowledge during the sixteenth century.

The manuscript's format reveals thorough involvement with the subject. ${ }^{66}$ The autograph does not have a title page nor a preface, the emergent features of the printed book. And yet it is clear that this autograph is a fair copy of a finalized text, a polished and pre-meditated writing that shows an understanding of the subject in its very organization. Eilburg did not disclose his sources. Instead, he referred to different passages of the book as Sefer Hashgahah [The Book of Providence], Tapuah ha-Zahav [The Golden Apple], Sod ha-Girmiyyah [The Secret of Heavenly Spheres], and so on, thus devising his own subtitles to different parts of the manuscript. He neatly presented these materials in the format of a father teaching his son-a popular rhetorical device as well as an actual reference to Eilburg's son, Abraham. Quire by quire, it reflects the learned medical curriculum (beginning with fevers and proceeding with the body's pathologies) to be concluded with medical astrology. This organization became commonplace at the thirteenth-century university, continuing through Eilburg's lifetime and into the following century. ${ }^{67}$

Over the course of the sixteenth and seventeenth centuries, the Ashkenazic physicians of Central Europe faced increasingly harsher attacks questioning the scholarly grounding of their medical practice. ${ }^{68}$ The pressure was simultaneous with the emergence of the German civic physician, who elevated the role of Galenism (medical scholarship) into an occupational identity. ${ }^{69}$ So did Eliezer Eilburg, who considered medicine "the external ladder to God." ${ }^{\prime 0}$ In its theory, he viewed medicine as harmonious with a selected body of philosophical thought and Jewish scholarship —an idea repeatedly emphasized in his first-person account. This harmonization was anything but intellectual innovation from the perspective of the readers of the medieval Hebrew medical

\footnotetext{
66 Ibid.

67 Jánošíková, "Composing Hebrew Medical Literature," 48-52, 62-64.

68 On the polemics targeting Jewish physicians, see John M. Efron, "Interminably Maligned: The Conventional Lies about Jewish Doctors," in Jewish History and Jewish Memory: Essays in Honour of Yosef Hayim Yerushalmi, eds. Elisheva Carlebach et al. (Hanover: Brandeis University Press, 1998), 269-308.

69 Hannah Murphy, A New Order of Medicine: The Rise of Physicians in Reformation Germany (Pittsburgh, PA: University of Pittsburgh Press, 2019); J. Andrew Mendelsohn, "Public Practice: The European 'Longue Durée' of Knowing for Health and Polity," in Civic Medicine: Physician, Polity, and Pen in Early Modern Europe, eds. J. Andrew Mendelsohn et al. (Abingdon: Routledge, 2020), 7-63. 
translations. ${ }^{71}$ Eilburg was merely following the way medical knowledge had been studied, interpreted, and performed south of the Alps for the past two centuries. ${ }^{72}$ Yet his turn to this particular Jewish (and non-Ashkenazic) library not only signals the library's extension to new cultural and geographical territories. It is also a witty response to the pressure exerted on a Jewish medical practitioner by Central European cities and their learned physicians entering the municipal administration.

Eilburg could acquire medical teaching that praised the theoretical as well as the practical through his Italian tutor, Judah d'Ascoli (also known as Ashkelon). D'Ascoli taught him biblical exegesis and its esoteric tradition, and medicineindeed, the very combination of scholarship and skills far more common to Italy than Central Europe. ${ }^{73}$ Eilburg praised d'Ascoli's linguistic skills; he spoke "the language of the Zohar but also sometimes the language of the Jerusalem Talmud, and the language of Syria."74 Eilburg listened to d'Ascoli's daily homilies, and noted the struggles that d'Ascoli's wisdom and linguistic proficiency posed for him. ${ }^{75}$ It is, therefore, difficult to assess d'Ascoli's real impact, as his image was clearly designed to be juxtaposed to his_-according to Eilburgignoramus Ashkenazic counterparts.

Joseph Davis identified d'Ascoli with the figure of a Roman physician and a young dignitary accompanying David Reuveni during his mission to Rome around ${ }^{1525} \cdot{ }^{76}$ In case Davis is right, d'Ascoli must have moved to Ancona in the footsteps of other Roman Jews after the city (formerly an independent port) was incorporated into the Papal State in 1532. The port became a safe haven for merchants of "all nations" in $1534,{ }^{77}$ but the burgeoning life of its Jewish communities was thwarted by the papal attack on the New Christians

71 Gad Freudenthal, "Arabic and Latin Cultures as Resources for the Hebrew Translation Movement: Comparative Considerations, Both Quantitative and Qualitative," in Science in Medieval Jewish Cultures, ed. Gad Freudenthal (Cambridge: Cambridge University Press, 2011), 79.

72 For an example of the intellectual profile of an Italian Jewish physician, rabbi, and teacher, see Ruderman's cultural biography of Abraham Yagel: David B. Ruderman, Kabbalah, Magic, and Science: The Cultural Universe of a Sixteenth-Century Jewish Physician (Cambridge, MA: Harvard University Press, 1988).

73 JTSA, Ms 2324, fol. 7ov, 94r, 10ov; JTSA, Ms 2692, fol. 8r-v, 24r.

74 Translation taken from Davis, Eliezer Eilburg, 224; cf. JTSA, Ms 2324, fol. 94r.

75 JTSA, Ms 2324, fol. 94r.

76 Davis, Eliezer Eilburg, 38, 224.

77 On Ancona, see Benjamin Ravid, "A Tale of Three Cities and Their Raison d'état: Ancona, Venice, Livorno, and the Competition for Jewish Merchants in the Sixteenth Century," Mediterranean Historical Review 6 (1992): 138-162 (140-141); Bernard Dov Cooperman, "Portuguese 'Conversos' in Ancona: Jewish Political Activity in Early Modern Italy," in In Iberia and Beyond: Hispanic Jews between Cultures, ed. Bernard Dov Cooperman 
in $1555 .{ }^{78}$ By that time, Eilburg was back in Central Europe, experiencing hardship of a different kind.

\section{$3 \quad$ The Passions of Knowing}

Eilburg's version of On Cardiac Drugs by Ibn Sīnā contains notes and comments integrated into the main text. One of them carefully clarifies the circumstances surrounding its production:

For nine months, I have toiled and found, until now; [from] Tishri [of the year] alluded in [the verse] the lion's roar (Hosh 11:10) of the minor era [= September/October 1553]; the time shall come for the release, w[ith the] h[elp of] G[od], it will [turn] into goodness, joy, and happiness in the allusion to the year of "praise" of the minor era $[=1554],{ }^{79}$ thanks to my Creator, the Maker of the world, $\mathrm{m}$ [ay He be blessed].

His [is] splendor and praise that cheered me up and awakened me in my solitude, in my captivity [that multiplied] the inner happiness of my intellect. If not for $\mathrm{G}$ [od], $\mathrm{Bl}[$ essed be He], who helped me, then I might have gone insane with grief from the duration of my imprisonment. But with this joyful awakening of the inner spirit, I grew stronger to become a man. ${ }^{80}$ Anger [at] an enemy did not cross my mind and my poverty was all forgotten. I have spent day and night [with] the joys of the Torah and with mathematics and physics [hokhmot limudiyot ve-țiv'iyot $]^{81}$ until I

(Cranbury, NJ: Associated University Press, 1998), 305-313; Peter Earle, "The Commercial Development of Ancona, 1479-1551," The Economic Historic Review 22 (1969): 37.

78 Serena Di Nepi, "Jews in the Papal States between Western Sephardic Diasporas and Ghettoization: A Trial in Ancona as a Case Study (1555-1563)," in Religious Changes and Cultural Transformations in the Early Modern Western Sephardic Communities, ed. Yosef Kaplan (Leiden: Brill, 2019), 291-322.

79 In a chronogram, Eilburg referred to autumn 1553 as the initial time of his imprisonment, which took nine months until the moment he wrote these words. Therefore, he wrote these words around July 1554 .

8 o Cf. 1 Sam 4:9.

81 Here, Eilburg refers to the division of theoretical philosophy into mathematics (arithmetic, geometry, astronomy, and music), physics, and theology. See Maimonides, "Treatise on Logic," tr. Moses ben Samuel ibn Tibbon, in Maimonides' Treatise on Logic. The Original Arabic and Three Hebrew Translations, ed. Israel Efros (New York: American Academy for Jewish Research, 1938), 59-61 (Hebrew pagination) [Hebrew]. The same division recalled in Moses Isserles, Torat ha-'Olah, I:7. 
brought my mind and intellect, t[hank] G[od], [back] to joy. Joyful things strengthen a man in [his] desires and he shall reach for what he aims. ${ }^{82}$

This comment is more than a scribal curiosity. Stating the problem, the place, the circumstances, followed by the applied remedies and their result, the micronarrative forms a medical proto-observation. ${ }^{83}$ The content may seem mundane rather than a reflection on a systematic theory and practice. But its larger (con)textual setting reveals Eilburg's thorough involvement with the concept of emotions and their bodily dimension presented in On Cardiac Drugs, as well as with the medical (and philosophical) theory that defined the medieval naturalization of emotions - in contemporary literature also known as accidents of the soul, passions, the movements of the vital spirit born in the heart.

The comment stems out of the discussion concerned with exhilarants. It is a reaction to the idea that the feelings stemming out of solitude may be diffused by activities of the opposite nature..$^{84}$ But if the remedy requires more company in the patient's life, what would the options be of an imprisoned man? The second part of On Cardiac Drugs provides a list of remedies to rectify the saddened, fear-stricken, and even exhilarated hearts, bringing the body to balance in the spirit of humoral medicine. This part is not included in Eilburg's Ma'arekhet Refu'ot ha-Shamayim (although he likely had access to it). As the studied text implies, there were ways to influence one's emotions, if one understood their motions and bodily and reactionary situation, and applied this knowledge to practice. Eilburg's recounted actions indeed suggest that they were guided by these theories. His comment here thus functions as proof that

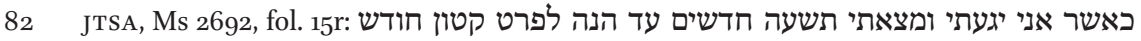

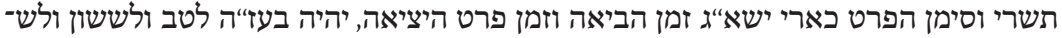

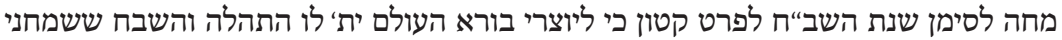

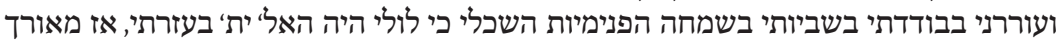

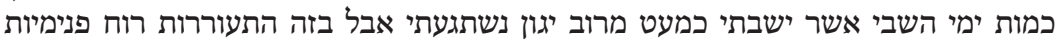

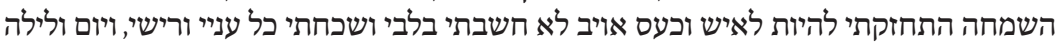

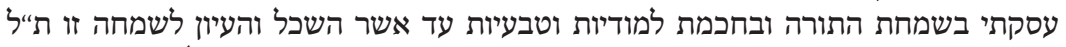
הביאיני, כי מהדברים המשמחים החזיק האדם במות במה שיחשות ערוק, והגיעו [sic] אל מה שיכות לשוין.

83 On observations in sixteenth-century Europe, see Gianna Pomata, "The Medical Case Narrative: Distant Reading of an Epistemic Genre," Literature and Medicine 32 (2014): 1-23 (8).

84 For English, you may consult translations of On Cardiac Drugs in Hakeem Abdul Hameed (ed. and tr.), Avicenna's Tract on Cardiac Drugs and Essays on Arab Cardiotheraphy (New Delhi: Hamdard Foundation Press, 1983), 19. The text, however, is not a critical edition. Note, the Arabic text and the Latin text (and their respective Hebrew translations) have different chapter numberings; Chapter 4 on exhilarants in the Arabic original appears as Chapter 5 in the Latin text (and Eilburg's Latin-to-Hebrew translations). 
studying and copying went hand in hand with a personally practiced verification of the studied content.

According to Ibn Sīnā, "[j] oy, grief, fear, and anger are reactions specific to the soul (pneuma) located in the heart." 85 Emotions were produced in reaction to impulses. ${ }^{86}$ They were reactions to a sensory input evaluated by the power of estimation, localized in the brain. Like "the sheep judging that this wolf is something to flee from," ${ }^{87}$ estimation enabled the extraction of information concerned with sensory knowledge that went beyond its sensory nature. ${ }^{88} \mathrm{In}$ this process, the attraction or repulsion towards the processed images developed (then stored in the memory) side by side feelings of grief, joy, fear, or anger. The information that caused emotional response, therefore, objectively existed. Avoidance, a measure to prevent such inescapable emotional upheaval, was thus medically proven advice. Eilburg's study of philosophy (the Torah, mathematics, and physics ${ }^{89}$ as a therapeutic activity thus seems much aligned with the strategy of diffusing one's attention, promoted by regimens of health. ${ }^{90}$

Yet his words imply more than mere disengagement. Studying employed the very same faculties which reacted to impulses, eventually producing emotions. The molding of one's emotional life and by extent cognition was thus far more demanding. But in controlling the latter, the strictly medical advice often met with the philosophical, theological, and mystical traditions of knowing (God). As Maimonides (d. 1204), a Jewish physician, writes in his regimen of health

85 Translation my own; cf. JTSA, Ms 2692, fol. 14r. For an English translation of the Arabic original, see Hameed, Avicenna's Tract, 14. In its Hebrew version, the term for reaction used by Eilburg is hitpa'alut - that is, affection or change caused by an agent.

86 Dag Nikolaus Hasse, Avicenna's 'De anima' in the Latin West: The Formation of a Peripatetic Philosophy of the Soul: 1160-1300 (London: The Warburg Institute, 2000), 127-137.

87 Cf. Fazlur Rahman (ed.), Avicenna's De anima (Arabic Text): Being the Psychological Part of Kitāb al-Shifä' (London: Oxford University Press, 1970), 45; Simone Van Riet (ed.), Avicenna Latinus. Liber de anima seu sextus de naturalibus. Edition critique de la traduction latine médiévale (Louvain: Ed. Orientalis; Leiden: Brill, 1968), 89, line 48; Hasse, Avicenna's De anima, 129; in reference to Avicenna, De Anima I, 5.

88 Hasse, Avicenna's 'De anima', 137.

89 See $\mathrm{n} 8$.

90 On the theory of six non-natural things, see L. J. Rather, "The Six Things Non-Natural: A Note on the Origins and (Fate of) a Doctrine and a Phrase," Clio Medica 3 (1968): 337-347; Saul Jarcho, "Galen's Six Non-Naturals: A Bibliographic Note and Translation," Bulletin of the History of Medicine 44 (1970): 372-377; on regimens of health, see Klaus Bergdolt, Wellbeing: A Cultural History of Healthy Living, tr. J. Dewhurts (Cambridge: Polity, 2008); Marilyn Nicoud, Les régimes de santé au Moyen Âge, 2 vols. (Rome: École française de Rome, 2007); Sandra Cavallo and Tessa Storey, Healthy Living in Late Renaissance Italy (Oxford: Oxford University Press, 2014). 
for al-Malik al-Afdal (d. 1225), the future Muslim ruler of Egypt: "[T]he physician, inasmuch as he is a physician, his art does not demand knowledge of the stratagem to remove these passions. For this matter is only attained by practical philosophy and by the admonitions and disciplines of the Law."91

Thus, the Jew prescribed the Muslim client a remedy to dilate his melancholystricken heart. ${ }^{92}$ Any preventive advice, however, could not be found in Maimonides' medical works written for wider Arabic readership, but in his religious and ethical writings such as Mishneh Torah. One of its chapters presents a brief list of medical advice, closely mirroring the theory of six non-natural things (i.e., a learned regimen of health). Yet, as a Jewish legal book, it is preoccupied with one particular type of body—that of a Jewish learned man. ${ }^{93}$ His address was not only limited to this gendered social group; it was exclusive: "[O]ne finds that these passions only make a very strong impression on persons who have no knowledge of ethical philosophy, nor of the disciplines and admonitions of the Law, such as children, women, and the ignorant. For these, because of the softness of their soul, are anxious and fearful."94

The cultivation of the soul went hand in hand with the cultivation of the intellect, susceptible to being overpowered by emotions. ${ }^{95}$ The regulation of emotional responses, therefore, carried innate social and gendered significance. It became a part of the scholar's image, which intricately linked the exercise of emotional moderation with the production of the rabbinic (scholarly) persona. The very act of studying - the one activity that played such a crucial role in rectifying Eilburg's emotional state-was a variable in this equation, as it gave Eilburg the opportunity to project an image of a pious Jewish man and scholar even in moments of crisis.

Maimonides' program of self-perfection, namely that of the Guide of the Perplexed, ${ }^{96}$ then borrowed this theoretical framework to Abulafia's ecstatic Kabbalah. ${ }^{97}$ As Moshe Idel has observed, this process included an inner

91 Gerrit Bos (ed. and tr.), Maimonides: On the Regimen of Health. A New Parallel ArabicEnglish Translation (Leiden: Brill, 2019), 102.

92 Ibid., 94, 98.

93 Maimonides, Mishneh Torah, Sefer Madda', De'ot 4 (the medical regimen); see also De'ot $1-6$.

94 Translation taken from Bos, Maimonides: On the Regimen of Health, 104.

95 This idea is also expressed in On Cardiac Drugs. Cf. Hameed, Avicenna's Tract, 18-19.

96 Cf. Roslyn Weiss, "Maimonides on Perfecting Perfection," Harvard Theological Review 110 (3) (2017): 339-359; Idel, Abraham Abulafia's Esotericism, 43-44 (on theurgy and relations between human activity and the Divine); 46-70 (on Abulafia's connection to Guide of the Perplexed).

97 See n 95; and Moshe Idel, "Abulafia's Secrets of the Guide: A Linguistic Turn," Revue de Métaphysique et de Morale 4 (1988): 495-528; idem, "Maimonides' Guide of the Perplexed 
conflict - "the war of inclinations" as he phrased it—which allowed Abulafia (who also considered emotions products of the vital spirit, and reactive moving states) ${ }^{98}$ to "shape the life of a person in a manner that allows him to reach a mystical experience by means of his techniques."99 As the extract from Hayyei ha-'Olam ha-Ba illustrates, the emotions were indivisible from the mystical experience, generated by practical actions:

[W] hen he begins to practice letter-combination in his hitbodedut [seclusion], he will feel fear and trembling, and the hairs of his head will stand up and his limbs will shake. Afterward, if he prevails, the Spirit of the living God will pass over him, and the Spirit of God, of wisdom and knowledge, and the fear of the L[ord] will rest upon him. And it will appear to him as if whole his body, from head to toes (lit. limbs), is anointed by the anointing oil. And he shall be a servant of the Lord, and his messenger $[\ldots] \cdot{ }^{100}$

This passage, an example of the interiorized experience of struggle promoted in Abulafia's practical Kabbalah, cannot be found in Eilburg's text. It, nonetheless, shares some elements with Eilburg's micronarrative concerned with imprisonment. Hitbodedut (as solitude) was a state of physical and mental seclusion, a practice encouraged in Abulafia's ecstatic Kabbalah. ${ }^{101}$ Could its lessons be applied to the seclusion of an incarcerated prisoner? In any way, it would be an overinterpretation to consider Eilburg's "awakening of the inner

and the Kabbalah," Jewish History 18 (2004): 197-226; Nathan Hofer, "Abraham Abulafia's 'Mystical' Reading of the 'Guide for the Perplexed,' Numen 6o (2013): 251-279.

98 See for instance the passage on reproduction in Hayyei ha-'Olam ha-Ba (also featured in Eilburg's Mahberet ha-Me'assef), where "the thought begins in the brain, where it comes from an image. In the [faculty of] imagination, it breaks down and is differentiated over the heart. The heart creates the vital spirit [that] sets in motion the passion[s] (ta'awah) [...]." Abraham Abulafia, Hayyei ha-'Olam ha-Ba, ed. Amnon Gross (Jerusalem: Gross, 1998), 32.

99 Moshe Idel, "Inner Peace through Inner Struggle in Abraham Abulafia's Ecstatic Kabbalah," Journal for the Study of Sephardic and Mizrahi Jewry 2 (2009): 63-97 (81).

100 Translation partially taken from idem, "Hitbodedut as Concentration in Ecstatic Kabbalah," Studies in Ecstatic Kabbalah (Albany: State University of New York, 1988), 110. More on emotions (fear and trembling) in Abulafia's mystical experience, in idem, Mystical Experience, 74-77. See also Abulafia, Hayyei ha-'Olam ha-Ba, 16.

101 Moshe Idel, "Hitbodedut as Concentration in Ecstatic Kabbalah," 108-112; idem, "Hitbodedut as Concentration in Jewish Philosophy," Jerusalem Studies in Jewish Thought 7 (1988): 39-6o; Patrick B. Koch, Human Self-Perfection: A Re-Assessment of Kabbalistic Musar-Literature of Sixteenth-Century Safed (Los Angeles: Cherub Press, 2015), 176-18o. 
spirit" through Abulafia's kabbalistic prism solely on account of the structural parallels in these narratives describing bodily experiences.

The Abulafian connection, in relation to Eilburg's experience of imprisonment, resurfaces in another passage. Located in Mahberet ha-Me'assef, filled with practices concerned with letter-combinations and Abulafian extracts, the text brings to mind the above-cited passage and its mystical tradition far more vividly than the passages located in his medical manuscript:

[The Lord] gives relief to those in distress and in prison. ${ }^{102}$ I had nearly forgotten everything that I had learned and that I had collected. Yet through the kisses and caresses and desire [for] the Divine Intellect [ $\mathrm{ha}$ sikhli ha-eloqi], for which my soul and spirit was thirsty to study Torah, I held on and remembered a little bit, by virtue of Malkhut, and the law of righteousness. ${ }^{103}$ From the East, the Agent's [ha-po'el] light shined on me to conjoin [with me]. In accordance with the thought of my Maker, my work emerged from my brain and memories. And a spirit lifted me up, from the place where I had sat like a nail hammered into a board, into satisfaction. And I took my shattered quill and ink, to write out the matters that came running from my lips like a fountain, advancing and flowing urgently, by the power of divine emanation [shefa' ha-eloqi].104

Abulafia described hitbodedut [concentration] along with the separation from the lustful and long and intensive study as a way to attain the Divine knowledge. ${ }^{105}$ And in Eilburg's passage above, its attainment is far more clearly articulated.

Yet any divine or universal knowledge is not the main goal here. Instead, Eilburg focuses on the brain and the memory as dysfunctional organs and faculties. This passage is thus preoccupied with the same issue as his comment in On Cardiac Drugs, where he identified memory as the source of his grief and anger, then impacting his whole wellbeing. Both passages thus discuss the mechanisms of cognition and emotions as their mighty and impactful by-products and imply the need to modulate their flows as situated bodily processes.

The experiences described by Abulafia and Eilburg-sharing the focus on intellection-thus differ greatly in relation to man's (or the Jew's) body. Conjoining was foundational in Abulafia's prophetic-messianistic dimension.

\footnotetext{
102 Cf. Ps 4:2.

103 Cf. Song 3:11.

104 Translation my own; alternatively, Davis, Eliezer Eilburg, 226; cf. JTSA, Ms 2324, fol. 94v.

105 In Abulafia, Hayyei ha-'Olam ha-Ba, 7; in Eilburg's manuscript as JTSA, Ms 2324, fol. 38v.
} 
As Elliot Wolfson put it, the kabbalist's enlightened state of mind enabled him to unfetter the soul from "the chains of corporality."106 But in Eilburg's case, the prophetic (and ecstatic) aspect of the Abulafian techniques was suppressed. The body and the environment remained a part of any experience of supernatural.

Such an attitude towards prophetic aspects of knowing also permeates Eilburg's later work, Eser She'elot, which equally focused on naturalized epistemology. ${ }^{107}$ Writing in the century of messianic upheaval, Eilburg preoccupied with the inadequacy of rabbinic criteria for evaluating prophetic claims. His first she'elah addresses the proofs by miracle-making and foretelling future among other topics. ${ }^{108}$ Basing himself in earlier authorities, he presents them as natural rather than only supernatural skills and qualities also common among magicians and witches, astronomers, and other selected or learned individuals and groups that know how to interpret the nature and its relation to God. Miracles and deeds bringing awe were interwoven into the material world and so were one's aptitude to interpret them.

In a similar vein, conjoining could have not been a mere actualization of the soul. Eilburg depicts it as the actualization of the kabbalist's body and soul. Conjoining with the divine did not serve to channel new universal knowledge, but to repair cognition. Indeed, it is memory, firmly located in the body, that plays a crucial role in both of Eilburg's descriptions. In Ma'arekhet Refu'ot haShamayim, it is memory that brings about the images of enemies then overpowering his rational faculty, ${ }^{109}$ and in Mahberet ha-Me'assef, it is memory that fails him in conjuring the images, intentions, and other processed pieces of knowledge that would enable him to practice Judaism in its most embodied way. For Eilburg, conjoining thus was deeply seated in man's body, restoring his broken faculties and healing his soul along with the body.

The case of Eliezer Eilburg - a small hero of great microhistories rather than a bearer of a singular historical legacy — helps us to problematize the relationship between theory and practice. Doing so, his works help us to bring

\footnotetext{
106 Elliot R. Wolfson, "Abraham ben Samuel Abulafia and the Prophetic Kabbalah," in Jewish Mysticism and Kabbalah: New Insights and Scholarship, ed. Frederick E. Greenspahn (New York: New York University Press, 2011), 84.

107 See JTSA, Ms 2323, fol. 45r-77r (Davis, Eliezer Eilburg, 73-184).

108 On prophecy (The First Question), see JTSA, Ms 2323, fol. 5or -58r; for an English translation, see Davis, ibid., 89-118.

109 JTSA, Ms 2692, fol. 15 r.
} 
forward more nuanced accounts of the sixteenth-century transformation of Ashkenazic Jewry in particular, and further methodological observations concerned with the study of knowledge transfer and the history of (kabbalistic) practices in general.

As Elchanan Reiner has already shown, the reception of non-Ashkenazic works among Central and Eastern European Jews was not a one-way process. In the case of Halakhah, it eventually transformed the Ashkenazic culture of scholarship, giving it its own distinct face; and so did the kabbalistic and medical materials, which were transformed as they made their way north of the Alps with figures such as Eilburg. This deliberate process of knowledge exchange and its adaptation was wider than the solemn focus on print could suggest. It involved subjects and modes of study that did not take place in the more institutionalized settings of a yeshivah or later kloyz-at least not as their essential program. It takes us to prisons and to closed circles of masters and their apprentices. It factors in not only the "internal" Jewish discourse but also the status of Jews as a minority and as mercantile and medical experts living in a changing Europe. For instance, Eilburg's medical manuscript was not only a response to the demand for works associated with Italian and Sephardic Jews; it was also a response to the rising stakes of the physician's occupation in Central Europe.

Eilburg's relentless agency may appear to historians as a dead-end project. Many titles that he promoted as the foundation of his occupational makeover had become obsolete by the following generation. The medieval Hebrew medical translations were disused by the beginning of the seventeenth century. Evidence-wise, Eilburg's proclivity for Abulafia was rather unique and did not officiate the next chapter in Abulafia's reception. This image is, however, in stark contrast with the liveliness of these texts in Eilburg's hands. Reorganized, annotated, verified, and amended, they represented materials of high cultural capital and, as Eilburg's references to imprisonment show, bore the potential to generate real life solutions.

It seems that while certain intellectual traditions appeared and disappeared, some of their accompanying practices remained. The Lurianic Kabbalah associated with Safed led to the "psychological revolution" according to Jonathan Garb; its emphasis on individual "activism" was driven by the medical discourse according to Assaf Tamari. ${ }^{110}$ But how was it distinct from Eilburg's

110 Jonathan Garb, Yearnings of the Soul: Psychological Thought in Modern Kabbalah (Chicago: The University of Chicago Press, 2016), 22-46 (24); also idem, "The Psychological Turn in Sixteenth Century Kabbalah," in Les mystiques juives, chrétiennes et musulmanes dans l'Égypte médiévale, VII ${ }^{e}-X V I^{e}$ siècles: interculturalités et contextes historiques, eds. 
personal activism and his molding of a body of passions in a prison 1,6oo miles away? In terms of theory, the answer may be long and detailed. But what if we inquire about the way distinct practitioners engaged their bodies? Early modern Ashkenaz has been widely recognized as a culture less preoccupied with devising original mystical theories and far more inclined towards practical Kabbalah (or magical practices). ${ }^{111}$ And as we further disentangle the relations between theory and practice, as exemplified in the study of intentionality by Agata Paluch, ${ }^{112}$ we will find ourselves writing a history of the body, medicine, and Kabbalah that crosses traditional divides between schools of thought. Instead of analyzing the reception of individual titles and knowledge frameworks, this history will focus on collective and individual engagement with the body, the environment, and God. This case study, therefore, chose to present Eilburg's manuscripts not as an offshoot of a story that did not fully materialize but as a challenge to presentism. It may be that the epistemological corpora of early modern Ashkenaz were far more diverse than current scholarship recognizes, and that supposed tensions between various schools of thought were rather theoretical than practical.

G. Cecere et al. (Cairo: Institute français d'archéologie orientale, 2013), 109-124; idem, "Shame as an Existential Emotion in Modern Kabbalah," Jewish Social Studies 21 (2015): 89-122 (95); Assaf M. Tamari, "The Body Discourse of Lurianic Kabbalah" (PhD diss., Ben-Gurion University of the Negev, 2016) [Hebrew].

111 E.g., Yossi Chajes, "Rabbis and Their (In)Famous Magic: Classical Foundations, Medieval and Early Modern Reverberations," in Jewish Studies at the Crossroads of Anthropology and History: Authority, Diaspora, Tradition, eds. Ra'anan Boustan et al. (Philadelphia: University of Pennsylvania Press 2011), 58-79.

112 Paluch, "Intentionality and Kabbalistic Practices." 